\title{
Laczkó Mária
}

Kaposvári Egyetem Pedagógiai Kar Gyógypedagógiai Intézet, egyetemi docens

\section{A beszéd digitális korunkban pedagógusjelölt hallgatók értékítéleteinek tükrében}

Digitális korunkban nemcsak a mindennapok világában szorult háttérbe az élószó. Az oktatásban már néhány évvel ezelótt sem volt „divat" a szóbeliség, sokkal inkább az irásbeliség dominált például a számonkérések alkalmával. Sajnos ez a tendencia napjainkra sem változott. Az irás olyannyira elsódleges a szóbeliséggel szemben, hogy az ún. „beszédes” tárgyakban, mint a magyar nyelv és irodalom, történelem, földrajz is visszaszorulóban van a szóbeli feladatok vagy

a szóbeli számonkérés aránya. Jól illusztrálja mindezt egy friss

kérdốves felmérés eredménye, amelyben a megkérdezett leendó pedagógusok, gyógypedagógusok, logopédusok többsége vélekedett úgy, hogy a középiskolai magyar nyelv és irodalmi tanulmányaik során inkább irásbeli kommunikációs gyakorlatokat oldottak meg, s az érveléssel kapcsolatos feladataik is nagyrészt írásbeliek voltak (Laczkó, 2015a). Igy nem csoda, ha a jól ismert kép, amely szerint diákjaink nemcsak a kötetlen társalgási témákban, de a kötött szituációkban, az érettségi vizsgákon sem képesek szóbeli feleleteik.

adekvát tolmácsolására, egyre gyakoribb. Tény, hogy a digitális eszközök teremttette nyelv irásbeli munkáikban is egyre jobban tért

hódit, ami indokol(hat)ja az irott nyelvi regiszter normáinak tudatositását és az írásos gyakorlatokat. Ám nézetünk szerint az írás a legmagasabb rendú kommunikációs tevékenység, ami a beszédet és az olvasást egyaránt feltételezi.

\section{Bevezetés}

$\mathrm{N}$ apjainkban az élőszó mintha kevésbé fontos lenne, különösen a fiatalok kommunikációjában. Sokféle oka lehet ennek, de közöttük mindenképpen említendő az internetes kommunikáció, az online világ, amiben a fiatalok élnek. Ebben a virtuális világban a face to face kommunikáció egyre inkább visszaszorul, hiszen a világháló, a Facebook, az sms-üzenetekkel történő kapcsolattartás nem igényli ezt. Úgy is fogalmazhatunk, hogy a személyes interakciót az eszközös kapcsolattartás váltja fel, s az ehhez nagyon gyakran alkalmazott írott szövegek az sms-nyelv elemeiböl építkeznek (Román, 2009). A következményeket pedagógusokként, szülökként egyaránt tapasztaljuk, az empirikus vizsgálatok pedig objektív adatokkal támasztják alá. A tanulók nemcsak nehezen fejezik ki magukat szóban és írásban a kisebb szókincs, a mentális lexikon 
előhívási problémái miatt, hanem az írott és a szóbeli kommunikációjukban használt nyelvi regiszter közötti különbség sem érzékelhető. Így az ún. írott-beszélt nyelv következményeként a beszélt nyelvi hatások és hibázások írott szövegeikben is kimutathatóak (Buda, 2011; Laczkó, 2009b; Vallent, 2008). Ráadásul mindezt tetézi a szleng jelentős mértékü használata is, ami az újabb vizsgálatok tükrében úgy tünik, napjainkban a legkevésbé a lázadás jele, sokkal inkább megszokásból használják a fiatalok, hiszen egyszerüsíti kommunikációjukat, feloldja a társalgást (Parapatics, 2013, 2014). Talán ezzel magyarázható a gyakorisága is, amiről egy középiskolás diák már néhány évvel ezelőtt úgy vélekedett, hogy olyan gyakori a szleng a beszédében, hogy a szülei gyakran figyelmeztetik a „rendes” beszédre (Laczkó, 2007). S az sem véletlen, hogy mindezek következtében a pedagógus beszéde és beszédstílusa olyan nyelvi regisztert jelent a diákoknak esetenként, ami érthetetlen számukra. Jól tükrözi ezt egy pedagógus néhány évvel ezelötti véleménye, aki elmondása szerint célját az osztályában csak a diákok által használt közönséges stílusú, már-már tolvajnyelvi elemeket tartalmazó mondataival tudta elérni (Laczkó, 2007). A tanár-diák nyelvi regiszterbeli különbséget jól láttatja annak a legújabb vizsgálatnak az eredménye, amelyben azt tapasztalták, hogy a diákok a tanár ismeretközlő beszédéből készített jegyzeteikben a pedagógus választékos, szaknyelvi kifejezései helyett szinte mindig a kevésbé választékos, alacsonyabb stílusértékü szavakat, a köznyelvi kifejezések helyett pedig gyakran a diáknyelvi és a szleng változatokat rögzítették (Laczkó, 2015b).

Digitális korunkban azonban nemcsak a mindennapok világában szorult háttérbe az élőszó. Az oktatásban már néhány évvel ezelőtt sem volt „divat” a szóbeliség, sokkal inkább az írásbeliség dominált például a számonkérések alkalmával. Sajnos ez a tendencia napjainkra sem változott. Az írás olyannyira elsődleges a szóbeliséggel szemben, hogy az ún. ,,beszédes” tárgyakban, mint a magyar nyelv és irodalom, történelem, földrajz is visszaszorulóban van a szóbeli feladatok vagy a szóbeli számonkérés aránya. Jól illusztrálja mindezt egy friss kérdőíves felmérés eredménye, amelyben a megkérdezett leendő pedagógusok, gyógypedagógusok, logopédusok többsége vélekedett úgy, hogy a középiskolai magyar nyelv és irodalmi tanulmányaik során inkább írásbeli kommunikációs gyakorlatokat oldottak meg, s az érveléssel kapcsolatos feladataik is nagyrészt írásbeliek voltak (Laczkó, 2015a). Igy nem csoda, ha a jól ismert kép, amely szerint diákjaink nemcsak a kötetlen társalgási témákban, de a kötött szituációkban, az érettségi vizsgákon sem képesek szóbeli feleleteik adekvát tolmácsolására, egyre gyakoribb. Tény, hogy a digitális eszközök teremttette nyelv írásbeli munkáikban is egyre jobban tért hódít, ami indokol(hat)ja az írott nyelvi regiszter normáinak tudatosítását és az írásos gyakorlatokat. Ám nézetünk szerint az írás a legmagasabb rendủ kommunikációs tevékenység, ami a beszédet és az olvasást egyaránt feltételezi. A szóbeli társalgási kultúra és a beszédprodukció fejlesztése, a szóbeli kommunikáció gyakoroltatása ezért mindenképpen meghatározó jelentőségü. Különösen igaz ez napjaink digitális, az írásbeli kapcsolattartást preferáló világában, ahol nem a kifejező beszéd jelenti a követendő mintát a fiatalok számára. S minthogy e fiatalokból kerülnek ki a jövő nemzedékének pedagógusai is, kérdés, hogy vajon miképpen vélekednek a témáról, tudnak-e azonosulni a rájuk váró feladattal. Úgy véljük, hogy a pedagógusok, gyógypedagógusok a digitális technika világában is magyaráznak, megértetnek, elfogadtatnak, s ehhez beszédük, a gondosan megformált élöszó, a szabatos, tömör stílusú, logikai rendet tükröző mondanivaló minta a befogadók, a tanulók számára. Kifogástalan beszédkultúrájuk, beszéd közbeni magatartásuk, viselkedésük mintaként szolgálhat a mindennapi online kommunikációt gyakorló diákok számára is. A pedagógusoknak tehát a hangos megnyilatkozás szabályait a nyelv-beszédviselkedés hármas egységén belül kell napjainkban is megvalósítaniuk. A követelményeknek a pedagógus, gyógypedagógus jelölteknek is eleget kell vagy kellene tenniük. Fontos, hogy felsőfokú tanulmányaik idején megszokják a helyes és kifejező beszédet, 
hogy később valóban mintaadók legyenek. Minthogy a digitális kultúrának e hallgatók is aktív részesei, kérdés, hogy miképpen vélekednek a mai magyar társdalomban a nyilvános megszólalás követelményeiről, a kifejező beszédről, fontosnak tartják-e a szép beszéd mintaadó szerepét. Kérdés az is, hogyan látják kortársaik és a náluk fiatalabb ún. digitális nemzedék beszédkultúráját, annak a korosztálynak a beszédét, akiket belátható időn belül oktatni fognak, vagy akik beszédét korrigálniuk szükséges. A jelen tanulmány célja az, hogy a feltett kérdésekre pedagógusjelölt hallgatók vélekedése alapján adjon választ. Hipotézisünk szerint a pedagógus, gyógypedagógus hallgatók sincsenek mindig tisztában a nyilvános megszólalás követelményeivel, és a kifejező beszéd számukra sem a nyelv zenei elemeinek a mondanivalóhoz illesztett adekvát használatát jelenti, hiszen a beszédtechnika, beszédmüvelés vagy a retorika tárgyak, ahol ezeket alaposabban elsajátíthatnák és gyakorolhatnák, a középfokú oktatásban még mindig háttérbe szorulnak.

\section{Anyag, módszer, kísérleti személyek}

A hipotézis ellenőrzéséhez és a feltett kérdések megválaszolásához kérdőíves felmérésen alapuló vizsgálatot végeztünk. A kérdések a szép beszéd fogalmára, a fiatalok beszédének megítélésére, a fiatalok és a szép beszéd viszonyára, a beszédmúvelés és a beszédtechnika tanításának szükségességére, fontosságára kérdeztek rá. A kérdések között voltak ún. zárt kérdések és a válaszadók véleményét számon kérő nyílt kérdések is.

A kérdőívet első és másodéves egyetemi hallgatók töltötték ki. Átlagéletkoruk 20,6 év volt, valamennyien ugyanazon az egyetemen tanulnak, gyógypedagógus hallgatók. Későbbi munkájuk szerves részét képezi nemcsak a beszéd tartalmi, hanem formai jegyeinek javítása, hiszen egy részük logopédusként fog dolgozni, egy másik részük pedig a tanulásban akadályozott tanulókkal foglalkozik majd. A vizsgálatban 60 hallgató vett részt, akik középiskolai tanulmányaikat többségében dunántúli középiskolákban végezték, de vannak közöttük budapesti hallgatók is. A hallgatók 85 százaléka gimnáziumban érettségizett, 15 százaléka szakközépiskolában. A válaszokat kérdésenként összegeztük, a statisztikai vizsgálatokat az SPSS 13.00 verziójával végeztük. Mintegy 500 választ elemeztünk.

\section{Eredmények}

Elsőként arra voltunk kíváncsiak, hogy a hallgatók hogyan vélekednek a nyilvános megszólalás feltételeivel kapcsolatban. Így azt kértük tőlük, hogy az általunk megfogalmazott négy válaszlehetőséget rangsorolják, s a sorrendet a legfontosabbtól kezdjék a legkevésbé fontosig felállítva. A négy válaszlehetőség a következő volt: (a) grammatikailag helyesen beszélni, (b) helyes hangsúlyozással, megfelelő hangerővel és beszédtempóval megszólalni, (c) választékos, gazdag szókinccsel beszélni, (d) logikus felépítésben, megfelelö érveket alkalmazni a beszédben.

A válaszadók többsége iskolatípustól függetlenül a nyilvános beszéd legfontosabb ismertetőjegyének napjainkban a gazdag szókincset tartotta (1. ábra). A mondanivaló logikus felépítése, a megfelelö érvek használata a második helyre került, és ezúttal sem volt számottevő különbség a kétféle iskolatípusban érettségizők között. A grammatikailag helyes beszéd összességében a harmadik helyet foglalja el a rangsorolásban, s ezúttal a kétféle iskolában érettségizők válaszai eltérést mutattak. A gimnáziumban érettségizettek ezt sokkal fontosabbnak vélték, mint a szakközépiskolában végzők. A beszédtechnikai ismeretek megfelelő szintje, így a jó hangerő, a helyes hangsúlyozás, a dallamos beszéd és a kellő beszédtempó szorult az összesített adatok szerint a negyedik helyre, és jóval kisebb százalékos aránnyal, mint a harmadik helyet elfoglaló helyes grammatika. 
Vagyis a válaszadók a nyilvános megszólalás leginkább mellőzhető elemének a szupraszegmentumok megfelelő alkalmazását jelölték meg. Az iskola típusának hatása ezúttal is megmutatkozott, és meglepő módon a gimnáziumban érettségizettek vélték a nyelv zenei elemeit a nyilvános megszólalás legkevésbé fontos paraméterének. A sorrendiségre kapott válaszokat a statisztikai vizsgálat is megerösítette (egymintás teszt: $\mathrm{t}(3)=5,171$, $\mathrm{p}=0,014)$.

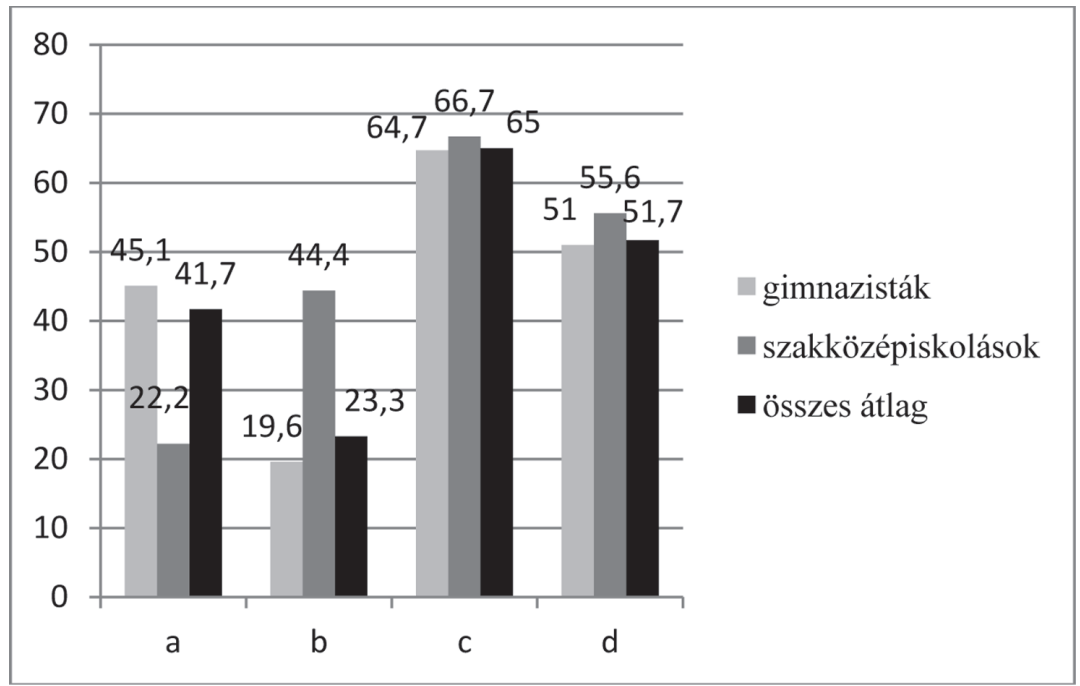

1. ábra. A nyilvános beszéd legfontosabb ismérvei a válaszok alapján (\%)

Jelölések: (a) grammatikailag helyesen beszélni, (b) helyes hangsúlyozással, megfelelő hangerővel és beszédtempóval megszólalni, (c) választékos, gazdag szókinccsel beszélni, (d) logikus felépítésben, megfelelő érveket alkalmazni a beszédben.

Az eredmények a bevezetőben írtakat jelenős mértékben alátámasztják, hiszen azt mutatják, hogy napjaink magyar társadalmában mindinkább a beszéd tartalmi oldalára helyeződik a hangsúly, a forma, az előadásmód kevésbé lényeges. A tartalom pedig jelentős mértékben a szókincs függvénye, valamint a gondolatok logikus elrendezésének és a meggyőzés képességének van alárendelve. A pedagógusjelölt hallgatók tehát a megszólalás formáját, a helyes hangsúlyozást, a beszéd tempóját, a kellő hangerőt, a dallamos beszédet maguk sem tartják fontosnak akkor, amikor megszólalnak, de azt igen, hogy mondandójukhoz megfelelö méretű adekvát szókincsük legyen, és azt is, hogy a véleményüket képesek legyenek logikusan felépíteni, és a másik fél számára meggyőzően tolmácsolni. A kérdés az, hogy lehetnek-e hitelesek mondandójuk továbbadásában és képesek-e a meggyőzésre, ha mindez kizárólag a szókincs mennyiségén és közleményeik logikai elrendezésén alapszik. Lehetnek-e sikeresek a nyilvános megszólaláskor, ha csupán a tartalomra koncentrálnak, ám az átadás módja már nem fontos számukra, ha a legfontosabb üzenetek közvetítését segítő és biztosító szövegfonetikai eszközök használatát már nem tartják lényegesnek? E kérdések felvetése különösen hangsúlyos lehet, hiszen empirikus vizsgálatok szerint a középiskolás fiatalok, akik közül a jövö pedagógusai kikerülnek, a mentális lexikonuk nagyságának és aktiválásának nehézségei mellett meglehetősen gyors tempóban közlik mondandójukat, és gyakran jellemző rájuk a monoton beszéd is (Laczkó, 2008, 2009c). S ugyanez elmondható a pedagógusképző intézményekben tanulókról is. A vizsgálatok megállapításai ugyan a hallgatók olvasásá- 
ra vonatkoznak, ám a szerzők utalnak arra, hogy a jelenségek spontán beszédükben még eröteljesebben érzékelhetőek (vö. Adamikné Jászó, 1991, 2000; Bóna, 2004).

Kíváncsiak voltunk arra is, hogy a hallgatók hogyan vélekednek a beszéd formai oldaláról. A kérdésünk arra vonatkozott, hogy mit jelent a szép beszéd fogalma számukra. Véleményeiket az ún. nyílt kérdés módszerével fejthették ki, így szabadon fogalmazhatták meg gondolataikat. A feltett kérdésre az alábbi válaszokat adták: nagy szókinccsel beszélni, helyesen, pontosan artikulálni, adekvát nyelvtani formákat alkalmazni, logikusan gondolkodni és logikus sorendben felépíteni a mondottakat, beszédhiba nélkül beszélni, megfelelő hangsúlyozással és beszédtempóval közvetíteni a mondanivalót, pontos, jól érthetö, világos stílusban fogalmazni, a káromkodást, a trágár beszédet mellőzni. A válaszok százalékos eloszlását a 2. ábra szemlélteti.

A hallgatók válaszaiban az első helyre a pontos artikuláció került, több mint 55 százalékos értékkel. Különösen a gimnáziumban végzők válaszaiban kapott ez nagy hangsúlyt, hiszen közel kétharmaduk vélekedett úgy, hogy a szép beszéd legfontosabb ismérve a megfelelő artikuláció. A második helyre valamivel kisebb százalékos értékkel, ám ez is 50 százalék körüli, a szókincs méretét és összetételét, milyenségét jelölték. A különböző iskolatípusban érettségizők válaszai ezúttal is eltértek, de az artikulációval összefüggő rangsorhoz képest ellentétesen. A két iskolatípusban érettségizettek válaszai között jelentősebb is a különbség, hiszen a szakközépiskolában érettségizők sokkal nagyobb mértékben tartották lényegesnek az adekvát szókincset a szép beszéd fontos jegyeként, mint a gimnáziumban végzettek. A nyelvtani helyesség, a grammatika tudása a harmadik helyet foglalta el a rangsorban, s jóval alacsonyabb százalékos értékkel, mint a pontos artikulációra, vagy a szókincsre adott válaszok. A különböző iskolatípusban érettségizett hallgatók válaszai ezúttal közel azonosak voltak. A hallgatók a beszéd formai jegyeiben lényeges szerepet betöltő szupraszegmentumokat, így a beszéd megfelelő tempóját, a helyes hangsúlyozást, a dallamosságot a nyelvtani helyességhez közeli százalékban a negyedik helyre rangsorolták. Az egyes iskolatípusokban érettségizettek válaszai között ismét nem volt lényeges eltérés. A szép beszéd fogalmának értelmezésekor az adekvát stílust is megemlítették, ám ezek kizárólag a volt gimnazisták válaszai voltak. Szintén csak a gimnáziumban érettségizett hallgatók válaszai között szerepelt a beszéd logikus felépítése és a beszédhiba nélküli beszéd is. S ugyancsak ők, nagyon kis százalékban, de jelölték a trágárság, a káromkodás nélküli beszédet is, ami figyelmeztető jel lehet.

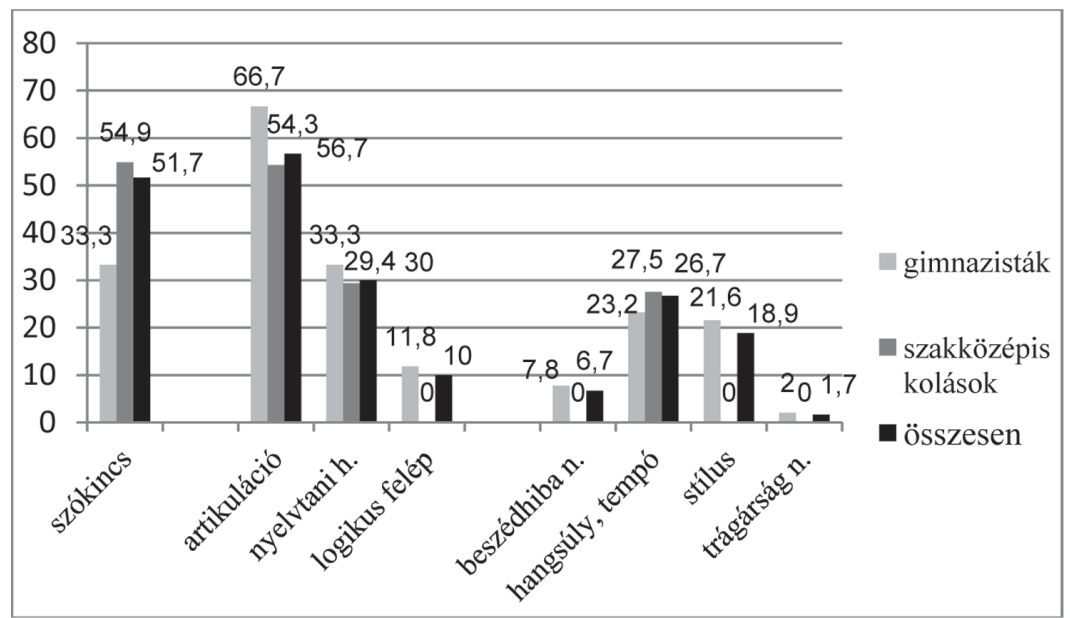

2. ábra. A szép beszéd fogalma a hallgatói válaszok tükrében (\%) 
Összességében a válaszok alapján az mondható el, hogy a vizsgált pedagógusjelölt hallgatók számára napjainkban a szép beszéd fogalma zömében a jól artikulált beszéddel és a gazdag szókincsü mondanivalóval fedhető le. A beszédhangok megformálásának a módja, az ajakartikuláció megfelelö müködése és a tiszta kiejtés, pontos hangzás tehát közel ugyanolyan lényeges ismérve a szép beszédnek, mint a szituációban helyesen elöhívott, jól használt lexéma. A grammatika helyessége és a szupraszegmentumok alkalmazása között sincs lényeges eltérés számukra, de ezek a szép beszéd fogalmában jóval kisebb szerepet kapnak, s még ennél is kisebb a jelentősége a stilisztikai jellemzőknek. A válaszok a nyilvános megszólalás legfontosabb ismérveinek rangsorolására adott sorrendiséggel szorosan összefüggnek, hiszen a szókincs elsődlegessége és a nyelv zenei elemeinek (a szövegfonetikai eszközöknek) a mondanivalóban betöltött legkevésbé fontos szerepe tükröződött ezúttal is.

Arra a kérdésünkre, hogy megítélésük szerint fontos-e a szép beszéd a mai fiataloknak, az elvárásainknak megfelelő válaszok születtek (3. ábra).

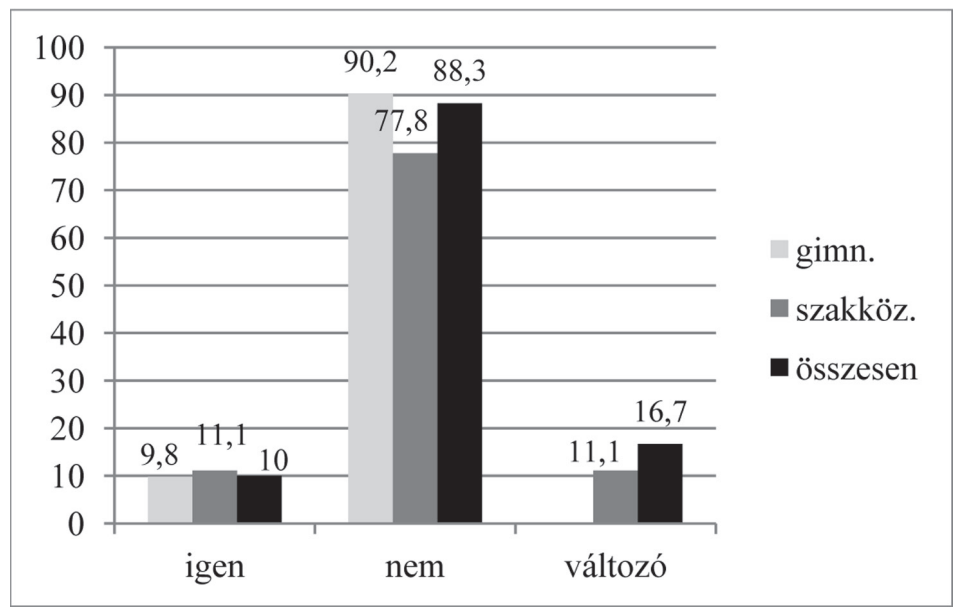

3. ábra. Fontos-e a fiataloknak a szép beszéd? (\%)

A hallgatók túlnyomó többsége nemleges választ adott, ám a kétféle iskolatípusban érettségizők közül a gimnazisták voltak többségben. Ez összefügg azzal, hogy a szakközépiskolában végzettek a kérdésre változó választ is adtak. A hallgatók nemleges válaszai igen beszédesek, különösen, ha az indoklásokat is megnézzük. Ezekben egyértelmüen szerepel, hogy az elektronikus kapcsolattartás miatt egyáltalán nem igénylik a beszéd formai oldalára való odafigyelést, a technika világában nem fontos ez, s arra is utalnak, hogy manapság a médiában sem lényeges ez. Azt is világosan megfogalmazzák, hogy a gyakori internet-használat miatt rövidítenek, keveset beszélnek, szegényes a szókincsük és gyakori a szóismétlés náluk. Az indoklások között olyan válaszok is találhatók, amelyek a fiatalok érdektelenségével, közönyével magyarázzák azt, hogy nem fontos számukra a hangzó beszéd megjelenési formája. A pontos artikuláció, az igényes kiejtés, a választékos stílus, az értelem tükröztetése vagy a kellő szintü tempó, megfelelő hangsúlyozás, amelyek a szép beszéd fogalmát jelenthetik, így egyértelműen elértéktelenedik, hiszen a szleng használata és a lazább stílus is elegendő és megfelelő számukra a mindennapi kommunikációban. A kérdésre igennel válaszolók a beszéd formai jegyének fontosságát a tekintéllyel magyarázzák. Azt fogalmazzák meg e válaszokban, hogy az igényes meg- 


\section{A hallgatókat a nyilt kérdés}

módszerével arra is megkértük, hogy minôsitsék a fiatalok beszédét. Nem adtunk támpontot ahhoz, hogy tartalmi vagy formai szempontból, mert arra is kíváncsiak voltunk, hogy vajon melyik szempontot fogják kiemelni a fiatalok beszédének minósítésekor. Válaszaikban a formai szempontok domináltak, tették: a szleng eróteljes haszná-

lata, sok rövidités, trágár beszéd, rövid válaszadás, helytelen, hibás hangképzés, helytelen nyelvtani formák használata, hadarás, idegen szavak használata, a szemtól szembe beszéd hiánya, kevés szókincs, sok szóismétlés, leegyszerúsített kommunikáció, vázlatos beszéd, a tisztelet hánya a beszédben. A válaszok százalékos megoszlásában (4. ábra) az elsố helyet a szleng kiemelkedô használata adja. a következó minósitéseket emlí-

szólalás, a szép beszéd tekintélyt ad a megszólaló személyének, akinek a mondandója így hangsúlyosabb lehet, mások számára megfontolandó üzenetet hordozhat.

A hallgatókat a nyílt kérdés módszerével arra is megkértük, hogy minősítsék a fiatalok beszédét. Nem adtunk támpontot ahhoz, hogy tartalmi vagy formai szempontból, mert arra is kíváncsiak voltunk, hogy vajon melyik szempontot fogják kiemelni a fiatalok beszédének minősítésekor. Válaszaikban a formai szempontok domináltak, a következő minősítéseket említették: a szleng erőteljes használata, sok rövidítés, trágár beszéd, rövid válaszadás, helytelen, hibás hangképzés, helytelen nyelvtani formák használata, hadarás, idegen szavak használata, a szemtől szembe beszéd hiánya, kevés szókincs, sok szóismétlés, leegyszerüsített kommunikáció, vázlatos beszéd, a tisztelet hánya a beszédben. A válaszok százalékos megoszlásában (4. ábra) az első helyet a szleng kiemelkedő használata adja. Ez a minősítés a válaszok csaknem fele (40 százalék), s különbség mutatkozik a kétféle iskolatípusban érettségizettek válaszai között. A gimnáziumban végzettek jóval kisebb arányban jelölték jellemző tulajdonságnak, mint a szakközépiskolában érettségizettek. A különbséget a statisztikai vizsgálat is igazolta (egymintás t próba: $\mathrm{t}(2)=7,428, \mathrm{p}=0,018)$. Kérdés, hogy ez annak tudható-e be, hogy a gimnáziumi tanulók gyakrabban használják a szlenget és ezért kevésbé észlelik, vagy a szakközépiskolások használják ezt a nyelvváltozatot gyakrabban, és ezért választják gyakoribb jellemzőnek, ami a mai fiatalok általános nyelvhasználatát tükrözheti.

A válaszok között a második helyen a trágár beszéd szerepel. Feltűnő, hogy a mai fiatalok beszédét trágárnak, káromkodással telinek elsősorban a gimnáziumban érettségizett hallgatók gondolják, a szakközépiskolában végzettek ezt a minősítést sokkal kisebb arányban jelölték, noha a csoportok válaszai között ezúttal is szignifikáns az eltérés (egymintás t próba: $t(2)=34,251, p=0,001$ ). Így ismét megválaszolandó, hogy vajon mi állhat e különbség hátterében. Feltételezésünk szerint lehetséges az, hogy a szakközépiskolások gyakrabban beszélnek ilyen módon, és emiatt kevésbé feltünő számukra a káromkodás, a trágár kifejezések használata, ezért a fiatalok beszédére adott minősítéseikben sem jelenik meg. Ám az is elképzelhető, hogy a gimnáziumban érettségizett hallgatók saját tapasztalataikat felhasználva úgy vélik, hogy a mai fiatal gimnazisták is gyakran káromkodnak vagy beszélnek trágár módon, s ezért jelölik magasabb arányban ezt a minősítést. A káromkodással, a csúnya beszéddel szinte egyező százalékos értéket képvisel az artikulációs problémát jelző minősítés. Vagyis 


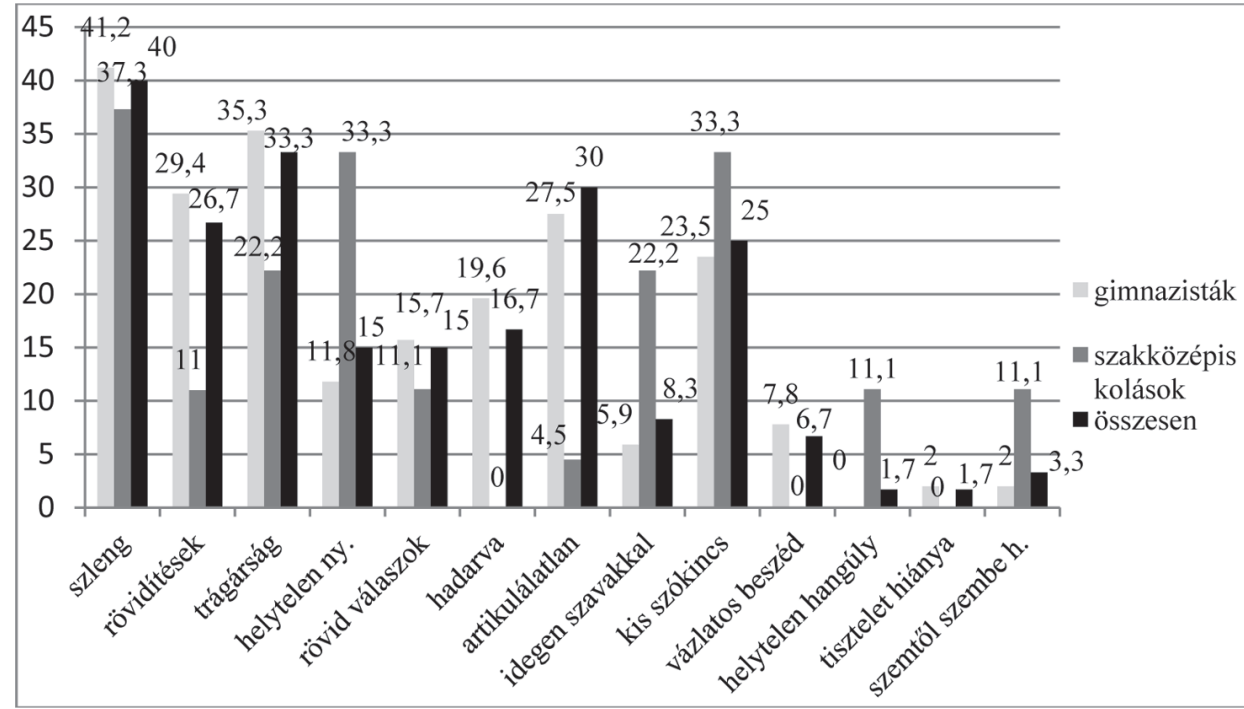

4. ábra. A fiatalok beszédének minösitésére adott válaszok (\%)

a fiatalok renyhe artikulációja, a zártszájú beszéd a pedagógusjelölteknek is igencsak feltünik, ám ez elsősorban a gimnáziumban végzettek számára negatív jelenség, hiszen a szakközépiskolában érettségizett hallgatók alig jelölik e minősítést. Ennek a különbségnek a hátterében is többféle magyarázatot gondolhatunk. Elképzelhető, hogy valóban van eltérés a gimnáziumi és a szakközépiskolai tanulók artikulációja között, és a gimnáziumban tanulók többségének artikulációja pontos, a beszédhangok helyes képzésére jobban ügyelnek. Ennek oka lehet az, hogy a gimnáziumba többnyire válogatás során kerülnek a diákok, s a felvételi beszélgetéskor esetleg szempontként érvényesül beszédük minősítése is. Az is elképzelhetö, hogy a gimnáziumban több időt szánnak a beszédmüvelésre, a szóbeli kommunikációs gyakorlatokra, amelynek keretén belül a tiszta és pontos hangoztatást célzó gyakorlatok számításba jönnek. Így a gimnáziumban tanulók érzékenyebbek lehetnek az artikulációs problémákra, és a kortársaik vagy a fiatalabbak beszédében hamarabb észlelik az artikulációs rendellenességet, így a kérdésünkre is magasabb arányban adhatnak ezzel kapcsolatos választ. Egy kérdőíves vizsgálat eredménye azonban azt mutatta, hogy a szakközépiskolában érettségizők valamelyest nagyobb arányban vélekedtek úgy, hogy beszédmüvelés, beszédtechnika, retorika tárgyakat tanultak, mint a gimnáziumban végzettek, kommunikációs gyakorlatuk is több volt, és több szóbeli érveléses feladatot is kaptak (Laczkó, 2015a). Vagyis a felmérés eredménye, éppen ellenkezőleg, arra világított rá, hogy a szakközépiskolában fordítanak több gondot a szóbeli beszédkultúra fejlesztésére, köztük az artikulációs gyakorlatokra, vélhetően azért, mert e tanulók szóbeli kifejezőkészsége és artikulációja ezt jobban igényli. Így az, hogy a gimnáziumban érettségizettek nagy számban, a szakközépiskolában végzettek pedig alig jelölték az artikulációs problémát a mai fiatalok beszédének minősítésekor, azzal is magyarázható, hogy a szakközépiskolai tanulók számára a renyhe artikuláció vagy a helytelen hangképzés kevésbé észlelt negatív jellemző kortársaik beszédében. A rövidítés és a kis szókincs szinte közel azonos százalékot képvisel a minősítésben az összesített adatok alapján, ám a különböző iskolatípusban érettségizők megítélése ezúttal is eltérően alakul. A gimnáziumban érettségizettek jóval magasabb százalékban 
minősítik a fiatalok beszédét a rövidítések alkalmazásával, mint a szakközépiskolában végzett hallgatók (egymintás t próba: $\mathrm{t}(2)=3,899, \mathrm{p}=0,06$ ), a szókincs esetében pedig fordított a helyzet. A fiatalok kevés szókincsét a szakközépiskolában érettségizettek jelölik nagyobb arányban, noha a különbség ezúttal a két iskolatípusban végzők között nem akkora, mint amekkora a rövidítésekre adott válaszokban (egymintás t próba: $\mathrm{t}(2)=8,947$, $\mathrm{p}=0,012$ ). A két iskolatípusban végzett hallgatóknak az ellentétes álláspontja összefügghet és ugyanazzal magyarázható. A szakközépiskolában végzettek a kis szókincset magasabb arányban nevezhetik meg, amiben a saját tapasztalatuk játszhat szerepet, ám a gimnáziumban végzettek szintén emiatt jelölhetik ezt a minősítést kisebb arányban. A rövidítések használatának a gimnazistáknál mutatkozó magasabb előfordulása szintén a gyakorisággal és a tapasztalattal lehet összefüggésben. Azzal, hogy maguk is gyakran élnek e lehetőséggel, és ezért úgy vélik, a fiatalokat is jelentős mértékben jellemzi. S bár a szakközépiskolások szintén gyakran használhatják a rövidítéseket, ám a túlzott használat számukra fel sem tünik, és ezért náluk kevésbé jelenhet meg a fiatalok beszédének a minősítésében. Talán nem véletlen, hogy a sorrendben a következő a rövid válaszokkal történő kommunikáció volt. A kis szókincs és a nagyfokú, többnyire az internet nyelvéből átvett rövidítések alkalmazása ugyanis jelentős mértékben hozzájárul ahhoz, hogy a mindennapi kommunikációban a teljes mondatokat, a hosszabb válaszokat kerüljék. Ez a sorrendiség azt mutatja, hogy a beszélt nyelvi rövidítések gyakori alkalmazása nem kedvez a szókincs bővülésének, és fordítva, a mentális lexikon nagyságával és előhívásával kapcsolatos nehézség a rövidítések használatát tovább erősíti, hiszen a diákok preferálják az internetes nyelv bevált rövidítéseit, és a nyelvi ökonómia rövid válaszokat és vázlatos beszédet eredményez.

A megkérdezett hallgatók a fiatalok beszédének minősítésére a következő sorrendben a grammatikai helyesség/helytelenség kategóriáját nevezték meg. Feltünő, hogy ebben a volt szakközépiskolások válaszai emelkedtek ki, ők a helytelen nyelvtani formákat a fiatalok beszédének jellemzésekor kétszer olyan magas arányban nevezték meg, mint a gimnáziumban végzettek. Ez az arány elgondolkoztató, és a magyarázat felveti azt a kérdést, hogy vajon a szakközépiskolában végzett hallgatók érzékenyebbek lennének a grammatikai formák helyes alkalmazására, vagy inkább arról van szó ismét, hogy saját negatív tapasztalatuk tükröződik a válaszokban, és azt érzékeltetik, hogy a szakközépiskolások grammatikai tudása nem elegendő. Érdemes a minősítésre adott válaszokból még a szövegfonetikai eszközökkel kapcsolatosakat, a hadarást és a helytelen hangsúlyozást megemlíteni. A tempó gyorsasága, amit a megkérdezettek úgy jelöltek, hogy a fiatalok „hadarva beszélnek”, csak a gimnáziumban végzett pedagógusjelöltek észrevétele volt, míg a helytelen hangsúlyozást jóformán csak a szakközépiskolában érettségizett hallgatók említették. Vagyis a szupraszegmentumok nem megfelelő alkalmazása a fiatalok beszédének minősítésében ugyan kevésbé fontos szempont a pedagógusjelöltek számára, mégis említendő e korosztály beszédének gyorsaságával és hangsúlyozásának hibáival kapcsolatos észrevételük, hiszen e szubjektív válaszok alátámasztják a témakörben végzett objektív kutatási eredményeket (Adamikné Jászó, 1991, 2000; Bóna, 2004; Laczkó, 2008, 2009b).

\section{Következtetések}

Felmérésünket azzal a céllal végeztük, hogy megvizsgáljuk, napjaink digitális világában lehet-e, van-e és milyen szerepe a kifejező beszédnek, és hogyan jelenik ez meg a leendő pedagógusok értékítéleteiben. Abból a gyakorlati tapasztalatból indultunk ki, hogy a digitális forradalom teremtette világunkban a kommunikáció új formája, az írásbeliség dominál, ami a szóbeliségre is hatással van. Egyfelöl a szemtől szembeni kommunikáció és a szóbeliség háttérbe szorul, másfelől az írott internetes kommunikáció teremtette 
nyelv a szóbeliségben is egyre jobban tért hódít. Hipotézisünk szerint ez föleg a mai fiatalok és az ún. digitális nemzedék beszédében követhető, akikből a jövő nemzedékét tanító pedagógusok kikerülnek. Választ kerestünk arra, hogy vajon a leendő pedagógusok, gyógypedagógusok miképpen gondolkodnak digitális világunkban a nyilvános megszólalás követelményeiről, milyen kritériumokat fogalmaznak meg a szép beszéddel kapcsolatban, fontosnak tartják-e a digitális technika világában a hangzó beszéd formai oldalát, és miképpen vélekednek a digitális nemzedék beszédkultúrájáról.

A kérdőíves felmérésben kapott eredmények azt láttatják, hogy napjaink kommunikációjában a szókincs megfelelő mennyisége elsődleges szempont. A megkérdezett hallgatók a szókincs gazdagságát, választékosságát nemcsak a nyilvános megszólalás legfontosabb követelményeinek nevezték meg, de a szép beszéd fogalmát is ezzel azonosították, és a fiatalok beszédének minősítésekor a szókincs nagysága szintén elsődleges jellemző volt. Kérdés, hogy vajon mivel magyarázható a szókincs dominanciája. Vajon azért szerepel a válaszokban kiemelkedő helyen, mert a pedagógusjelölthallgatók, akik maguk is a fiatal korosztályt képviselik, önmagukon is érzik a kifejezésbeli nehézségeket, a szókincstalálási kudarcokat a kommunikációs szituációkban? Érzik és tapasztalják, hogy nem tudnak megfelelő formában fogalmazni a szóbeli megnyilvánulásaikban, aminek gátja szókincsük mérete és/vagy a lexikális előhívás problémája? Vagy azért, mert mindezek mellett feltételezik, és nyilván látják/hallják is, hogy a náluk fiatalabb korosztály még inkább küzd e problémával? Egy 1990-ben készült felmérésben a pedagógusképző intézményben hallgatók mintegy negyede vélekedett úgy, hogy kifejezésbeli problémával küzdenek, aminek okaként kevés szókincsüket és a terjengős kifejezéseiket egyaránt megnevezték (Laczkó, 1990).

Összevetve e válaszokat a jelen felmérésben kapott eredményekkel, azt mondhatjuk, hogy negyedszáz év elteltével semmi nem változott. Ezt támasztja alá a jelen felmérés egy másik eredménye is, a hallgatóknak a beszéd tagolásában, a fontos gondolatok kiemelésében és ezzel a beszédfeldolgozásban is egyaránt lényeges szerepet betöltő szupraszegmentumokkal kapcsolatos attitüdje. A megkérdezettek nemcsak a nyilvános beszéd legkevésbé fontos paraméterének vélték a kellő tempót, hangerőt vagy a helyes hangsúlyozást és a dallamos beszédet, de a szép beszéd formai jegyei között ezek szintén nem preferált elemek voltak. Még a beszéd grammatikai helyessége, vagyis a nyelvtani szabályok beszédbeli alkalmazása is lényegesebb szempont értékítéleteikben. lllyés Gyula $(1975,44-45$. o.) azt írja, hogy „a beszéd és az írás módja mindenkit leleplez. Jól beszélni és írni magyarul, ez tehát igazából jellemkérdés". A beszéd tartalma mellett tehát a forma sem elhanyagolható, hiszen a legjobb tartalmat is tönkreteheti a rossz mondatszerkesztés, a nem adekvát szóválasztás, a helytelen hangsúlyozás, a megszólalás monoton módja. A megszólalás formája mindemellett rámutat(hat) a beszélő személyiségére, valakinek a jellemére, vagyis a beszélőtől elválaszthatatlan személyisége, ami beszédmódjában tükröződik. Ez pedig a szókincsen túl a helyes hangképzést, a pontos artikulációt és a szövegfonetikai eszközök alkalmazását is jelenti. Ám úgy tünik, mindez mai digitális világunkban egyáltalán nem lényeges, hisz nincs is rá szükség. Miért is lenne fontos, ha nem szemtől szembe és szóban, hanem jóformán virtuális térben és írásban zajlik a kapcsolattartást biztosító kommunikáció? Adamikné Jászó Anna 1991-ben, majd 2000-ben írt tanulmányaiban ismerteti azokat a vizsgálati eredményeket, amelyekben pedagógusjelöltek felolvasását elemezte. Megállapítja, hogy a monotónia jellemző hiba, amelyik a szövegfonetikai eszközök mellözéséből vagy helytelen alkalmazásából ered, és gyakran helytelen hanglejtésű lesz a beszéd (Adamikné Jászó, 1991). Egy másik vizsgálatban úgy fogalmaz, hogy 20 év alatt a föiskolai hallgatók beszéde változott, ami nemcsak a tempó gyorsításában és a vélhetően ennek következményeként fellépő rövidítési tendenciákban érhető tetten, de abban is, hogy a hallgatók jelentős hányada nem bánik megfelelően a hangsúllyal és a szünetekkel (Adamikné Jászó, 2000, 128. o.). Bóna 
Judit 2004-es vizsgálatában arra hívja fel a figyelmet, hogy a szupraszegmentumok hibái kiemelkednek, köztük is a monotonság, a mondatvég dallamának felemelése hangsúlyozandók, de a hangsúlyozás és hangerő hibái is nagyon gyakoriak, és a gyors tempó nála is szerepel. A szupraszegmentális szint hibáira kapott magas előfordulási arányok egyértelmüen összecsengenek a jelen felmérés eredményével, azzal, hogy a pedagógusjelölt hallgatók a beszéd szupraszegmentális szintjével kevésbé törödnek, holott ez a szint a tartalom közvetítésében és a beszédpercepciós müködésekben egyaránt jelentős szerepet játszik. Elgondolkoztató, hogy miként fognak így a beszéd közvetítette mintaadásban prominens személyekké válni. Ha pedig hibás mintát közvetítenek, az a tanórai tanár-diák kommunikációban félreértést eredményezhet, ami a tanári munka hatékonyságát szintén befolyásolja.

A hallgatóknak a mai fiatalok beszédével kapcsolatos válaszai szintén hangsúlyozandók. A jelen felmérés adatai is megerősítik mások vizsgálatait, amely szerint a fiatalok nyelvhasználatában a szleng olyan eröteljesen érvényesül (vö. Parapatics, 2013, 2014), hogy szinte kézenfekvő, hogy felismerni és javítani sem képesek (Laczkó, 2012). Úgy is fogalmazhatunk, hogy a mai fiatalok szleng szavainak használata nem csupán stílus, de egyfajta nyelvhasználati változás. S ez a változás napjainkban kiegészül a beszélt nyelvben alkalmazott rövidítésekkel és a következményesen fellépő leegyszerüsített kommunikációval, a hallgatók által vázlatos beszédnek nevezett jelenséggel. A kérdés az, hogy ez a fajta kommunikáció miképpen befolyásolja a humán megértési folyamatot.

A pedagógusjelölt hallgatók a mai fiatalok beszédében kiemelik a durva, trágár kifejezések használatát. Dóra Zoltán 1994-ben azt állapította meg, hogy a fiatalok szóhasználatát a durva stílus uralja, gyakran használnak agresszív kifejezéseik mellett trágár szavakat is (Dóra, 1994). Egy kísérletben azt találták, hogy a középiskolások a csúnya szavak alatt szinte csak a trágár, már-már vulgáris kifejezéseket értik, vagyis a durva stílusra fogékonyak a leginkább (Laczkó, 2009a). A jelen felmérés eredménye szintén ezt támasztotta alá, így ebben sem látszódik pozitív irányú változás.

Milyen pedagógiai tanulsággal jár felmérésünk eredménye? Mindenekelőtt azzal, hogy a pedagógusjelölteket is fontos a kifejező beszédre oktatni, tudatosítani kell bennük, hogy a beszéd tartalmi felépítése mellett mondandójuk formájára szintén ügyelniük kell. Ez nem csupán az artikulációs gyakorlatokat kell, hogy jelentse, de a szövegfonetikai eszközök tudatosítását is. S mindezzel nemcsak a magyar szakos hallgatóknak vagy a tanítóképzőben tanulóknak és a jövő logopédusainak kellene tisztában lennie, hanem minden pedagógusnak, aki oktatni kíván. Fontos azt a pedagógiai konzekvenciát is kiemelnünk, hogy a digitális forradalom „negatív vívmányaival” egyre inkább szembe kell néznünk, s ez a szóbeli beszédkultúra tanításának létjogosultságát a közoktatási intézményekben napjainkban erőteljesen igényli. Lehet, hogy szükség lenne a beszélgetés órák újbóli bevezetéséhez, hogy diákjainkat a kifejező beszédre neveljük?

\section{Irodalomjegyzék}

Adamikné Jászó Anna (1991): A kiejtési norma érvényesülése föiskolai hallgatók beszédében. In: Kemény Gábor és Kardos Tamás (szerk.): A magyar nyelvi norma érvényesülése napjaink nyelvhasználatában. MTA Nyelvtudományi Intézete, Budapest. 169-176.

Adamikné Jászó Anna (2000): Változott-e húsz év alatt a főiskolások kiejtése és olvasása? In: Gósy Mária (szerk.): Beszédkutatás 2000. MTA Nyelvtudományi Intézet, Budapest. 124-31.
Bóna Judit (2004): Tanárjelöltek beszédprodukciója felolvasáskor. Magyar Nyelvör, 128. 158-165.

Buda Zsófia (2011): Az internet hatása a nyelvhasználatra. Fiatalok fogalmazás és kifejezőkészsége az internethasználattal összefüggésben. XXI. század Tudományos Közlemények, 26. sz. 89-105.

Dóra Zoltán (1994): Diákjaink nyelvhasználata. Magyar Nyelvőr, 118. 1. sz. 54-57. 
Illyés Gyula (1975): Anyanyelvünk. Magvető, Budapest.

Laczkó Mária (1990): Főiskolások beszédkultúrájáról. Fejlesztő Pedagógia, 1. 4-5. sz. 44-45.

Laczkó Mária (2007): Napjaink tizenéveseinek beszéde szóhasználati jellemzők alapján. Magyar Nyelvör, 131. 2. 173-184.

Laczkó Mária (2008): Hogyan minősítik tizenévesek beszédét a diákok, és hogyan a tanárok? Anyanyelvpedagógia, 3-4. sz. 2015. 11. 28-i megtekintés, http://www.anyanyelv-pedagogia.hu/index. php?issue $=4$

Laczkó Mária (2009a): A szavak ereje napjainkban. In: Az anyanyelv az életemben. Válogatás az Oktatási Minisztérium anyanyelvi pályázataiból. (Szerk.: Balázs G. - Grétsy László) Tinta Könyvkiadó. Budapest. 115-127.

Laczkó Mária (2009b): Középiskolai tanulók spontán beszédének temporális jellegzetességei. Magyar Nyelvör, 133. 4. sz. 447-467.

Laczkó Mária (2009c): The consequences of various types of mistakes in children's writing. In: Lengyel Zsolt és Navracsics Judit (szerk.): Tanulmányok a mentális lexikonról. Segédkönyvek a nyelvészet tanulmányozásához. Tinta Könyvkiadó. 181-202.
Laczkó Mária (2012): Hogyan érzékeljük a stílust? Szleng kifejezések vizsgálata produkciós és percepciós szempontból. Magyar Nyelvör, 136. 4. sz. 439-456.

Laczkó Mária (2015a): A magyartanítás fonáksága: a nyelvtanóra és szerepe. Magyartanitás, 3. sz. 24-32.

Laczkó Mária (2015b): Középiskolai tanulók nyelvhasználata jegyzeteik tükrében (megjelenés alatt A Generációk nyelve konferencia kötetében).

Parapatics Andrea (2013): Fiatalok nyelvi mentalitása és a szleng. Doktori értekezés. Budapest.

Parapatics Andrea (2014): A szleng hagyományos funkcióiról a fiatalok szemével. Iskolakultúra, 24. 4. sz. $63-76$.

Román M. Mihály (2009): Az internet nyelve - Az új média szociolingvisztikai hatásai egy kutatás fényében. Konferencia-előadás: Új média, médiakonvergencia, kulturális változások. Sapientia - EMTE Múszaki és Humántudományok Kara, 2009. március 27-28., Marosvásárhely.

Vallent Brigitta (2008): Beszélt nyelvi hatások a középiskolások fogalmazásaiban. Magyar Nyelvőr, 132. 189-205. 